\title{
Heidegger e a questão da ética Entre as duas vias da questão do ser
}

\author{
Alexandre Franco de Sá
}

\section{Introdução: Heidegger e a questāo da ética como problemática metaontológica}

Uma das questões mais controversas no tratamento da filosofia heideggeriana consiste indubitavelmente na consideração da sua articulação com a fillosofia prática. Tal controvérsia não é, de modo nenhum, injustificada. E não o é, antes de mais, por razões que saem do estrito âmbito temático da filosofia. Ao considerar-se a biografia de Heidegger, particularmente a sua ascensão ao reitorado da Universidade Albert Ludwig, em Freiburg, no ano de 1933, com o apoio do Partido Nacional- Socialista, foi inevitável o aparecimento da questão acerca do modo como a filosofia heideggeriana se poderia articular com a acção do seu autor. Seria possível encontrar nesta filosofia o suporte meditativo de uma ética possibilitante do apoio político à Machtergreifung nacional-socialista? Seria possível ver no extraordinário sucesso das lições de Marburg e de Freiburg, lidas por Heidegger ao longo dos anos 20 e 30 , assim como no da publicação de Ser e tempo em 1927, a propagação na universidade alemã de um ambiente sentimental (no sentido de uma Stimmung) propício à eclosão do autoritarismo nacional-socialista? Ou seria que - como o próprio Heidegger sustentava na entrevista concedida em 1966 à revista Der Spiegel, postumamente publicada - este apoio consistiu apenas num acto de quem não se apercebera ainda da verdadeira natureza da revolução então emergente e, de um modo porventura ingénuo, esperava poder contrariar a vaga que então varria a Alemanha a partir do seu próprio movimento, contestando as suas tendências predominantes e mais terriveis - a elevação do povo a valor supremo (o pensamento völkisch), assim como o racismo e o biologismo?

Apesar das apaixonadas polémicas que semelhante tema naturalmente suscitou, sobretudo a partir da documentação reunida e publicada em 1962 por Guido Schneeberger ${ }^{1}$, o processo de publicação das Obras completas ${ }^{2}$ de Heidegger em curso na editora Vittorio Klostermann, particularmente a publicação das lições referentes aos anos 30, permite resolver definitivamente o dilema. Todavia, não o resolve na medida em que possibilita tomar partido por uma ou outra das posições

1 Cf. Guido SCHNEEBERGER, Nachlese zu Heidegger, Berna, 1962.

2 As referências que faremos às Obras Completas (Gesamtausgabe) de Heidegger serão indicadas com a sigla "GA", juntamente com o número do volume. 
mencionadas, mas, pelo contrário, na medida em que exige compreendê-las como não sendo mutuamente exclusivas. Dir-se-ia, à partida, que não é possível conceber uma filosofia, com a radicalidade e o alcance da filosofia heideggeriana, completamente situada fora da vida de quem a pensa. Se se pode afirmar, com Fichte, que a filosofia que se tem depende do homem que se é, não é menos verdade que também o homem que se é, na prática que constitui o seu agir no mundo, está na dependência da filosofia por ele pensada e, nesta medida, a pode manifestar. Não é então concebível que a adesão de Heidegger ao Partido Nacional-Socialista seja indiferente para a compreensão da dimensão prática - ético-política - da sua filosofia. Não se pode ignorar, por exemplo, que uma tal adesão ressoa já na antipatia heideggeriana diante de um tempo marcado pela funcionalidade técnica, pelo culto do progresso e do conforto, por uma "sociedade aberta" alimentada pela curiosidade fútil e pela banalidade das opiniões feitas de lugares comuns ${ }^{3}$. Mas se o comprometimento de Heidegger com o nacional-socialismo não pode deixar de ser considerado como filosoficamente significativo, é por esta mesma razão que se deve dar relevância à sua contestação ao pensamento völkish e ao racismo biologista, desenvolvida não apenas em textos escritos ao longo dos anos 30 e só postumamente publicados, como é o caso dos Contributos para a filosofia ${ }^{4}$, mas em lições públicas que criticavam corajosamente teses racistas e biologistas, chegando a mencionar como objecto dessa crítica autores e dirigentes nacionais-socialistas com a relevância de Alfred Rosenberg ${ }^{5}$.

Contudo, o choque entre a filosofia de Heidegger e a sua biografia não é a única fonte - nem sequer a mais interessante - a partir da qual a questão da sua articulação com a filosofia prática pode ser colocada. Deixando de parte os problemas suscitados pelo percurso biográfico de Heidegger, a questão da articulação da filosofia heideggeriana com o plano prático pode surgir a partir de um âmbito que se poderia caracterizar - para o distinguir do anterior - como estritamente filosófico. Heidegger coloca ele mesmo a questão na sua Carta sobre o "humanismo", ao reflectir sobre a publicação de Ser e tempo. Nela, refere a interrogação de «um jovem amigo» que, após a leitura de Ser e tempo, lhe teria perguntado: «quando é que escreve uma ética? $»^{6}$. À luz do projecto filosófico desenvolvido por esta obra, uma tal pergunta era aliás perfeitamente natural. E ainda o seria mais, se a pergunta tivesse sido formulada por um auditor das últimas lições do período de Marburg,

3 Poder-se-ia articular esta antipatia com uma curiosa definição de fascismo apresentada por Mussolini: «Quando recentemente um filósofo finlandês me pediu para dar numa frase uma definição do Fascismo, escrevi em alemão: nós somos contra a vida cómoda!» (Emil LUDWIG, Colloqui com Mussolini, Milão, Mondadori, 1932, p. 190, cit. por António José de BRITO (org.), Para a compreensão do fascismo, Lisboa, Nova Arrancada, 1999, p. 31).

4 Neste texto, ao qual nos referiremos adiante de um modo mais desenvolvido, publicado apenas por ocasião do centenário do nascimento de Heidegger, em 1989, e considerado por Otto Pögeller a sua segunda Hauptwerk, Heidegger classifica como «pura estupidez» a tentativa de distinguir o conhecimento e a ciência segundo critérios racistas (Cf. Beiträge zur Philosophie (Vom Ereignis), GA65, p. 163). No mesmo texto, Heidegger afirma ainda explicitamente que «o povo nunca pode ser meta e fim e que tal opinar é apenas uma extensão "völkish" do pensamento "liberal" do "eu" e da representação económica da manutenção da "vida"» (GA65, p. 319).

5 É de notar que Alfred Rosenberg, autor de $O$ Mito do Século $X X$, chefe de redacção do jornal oficinal nacional-socialista Völkischer Beobachter, ocupava um lugar destacado na hierarquia nacional-socialista. Nas lições do Semestre de Inverno de 1934-35, Heidegger critica-o explicitamente (Cf. GA39, p. 27).

6 Brief über den "Humanismus», GA9, p. 353. 
lidas no Semestre de Verão de 1928 e intituladas Princípios metafísicos da lógica a partir de Leibniz.

É no decurso destas lições que Heidegger atinge a maior clareza sobre o projecto filosófico da sua ontologia fundamental. E é nele que a necessidade de uma ética se torna, no contexto da elaboração integral da ontologia fundamental, explicitamente assumida. Com efeito, para o Heidegger das lições de 1928, a publicação de Ser e tempo, um ano antes, correspondia apenas a uma preparação para a questão do ser, através de uma analítica preparatória e, como tal, sumária do ente cuja essência consiste em pôr essa mesma questão. Tal analítica de um ente que é existência, que é aí-ser (Dasein) deveria conduzir à consideração do ser propriamente dito, completando-se a ontologia fundamental através da tematização dos quatro problemas fundamentais da ontologia: o problema da diferença ontológica entre ser e ente, o problema da articulação fundamental intrínseca ao próprio ser, o problema do seu carácter veritativo e, finalmente, o problema da conciliação entre a sua unidade e a multiplicidade das regiões ônticas ${ }^{7}$. Só depois, num segundo momento, se poderia voltar à análise do ente humano, considerando-o então de um modo completo e já ontologicamente fundamentado, naquilo a que se chamaria uma "ontologia regional", uma "ôntica metafísica" ou uma "metaontologia" da existência do próprio homem ${ }^{8}$. E é ao considerar esta segunda analítica do ente humano - uma analítica já não meramente preparatória, mas completa - que Heidegger escreve: «E aqui, na área do perguntar metaontológico-existencial, está também a área da metafísica da existência (só aqui se pode colocar a questão da ética)» ${ }^{9}$. O parêntesis não permite dúvidas sobre a orientação que Heidegger vislumbrava para a sua futura tematização metaontológica do aí-ser humano. Uma analítica do ente humano que ultrapassasse o carácter meramente preparatório de Ser e tempo, um tratamento da existência que, ultrapassando a ontologia fundamental, fosse meta-ontológica, seria o espaço em que poderiam abertamente surgir não apenas as questões antropológicas em geral, mas - e sobretudo - as questões práticas em particular.

Heidegger não continuou o projecto de elaboração da ontologia fundamental, pelo menos no "giro" (Kehre) cujo plano se traçava em $1928^{10}$. Aquilo a que se poderia chamar uma analítica integral da existência enquanto modo de ser do homem,

7 Sobre o carácter meramente preparatório de Ser e tempo e o esforço de Heidegger em completar o projecto da ontologia fundamental, cf. Friedrich-Wilhelm von HERRMANN, Heideggers» Grundprobleme der Phänomenologie». Zur "Zweiten Hälfte» von «Sein und Zeit», Frankfurt am Main, Vittorio Klostermann, 1991. Já nas lições do Semestre de Verão de 1927 - em Os problemas fundamentais da fenomenologia -, que constituem uma tentativa de elaboração da terceira secção da primeira parte de Ser e tempo (intitulada Tempo e ser), Heidegger aborda os quatro problemas ontológicos referidos a partir de quatro teses tradicionais sobre o ser (Cf. GA24, pp. 20-25). No Semestre de Verão de 1928, Heidegger retoma ainda mais claramente esses quatro problemas: "O título geral "ser" encerra estes quatro problemas fundamentais: 1. a diferença ontológica, 2. a articulação fundamental do ser, 3. o carácter veritativo do ser, 4. a regionalidade do ser e a unidade da ideia de ser» (GA26, pp. 193-194).

8 É nas lições do Semestre de Verão de 1928 que Heidegger introduz as expressões metaontologia (GA26, p. 199) e ôntica metafisica (GA26, p. 201). Em Ser e tempo, §§ 3-4, tinha-se-lhes referido como as ontologias decorrentes de uma ontologia fundamental.

9 GA26, p. 199.

10 De notar que o termo Kehre (aqui traduzido por "giro") ocorre pela primeira vez nestas lições, aludindo ao próprio movimento do projecto de oscilação entre a ontologia fundamental e as metaontologias. A passagem é a seguinte: «Este todo da fundamentação e elaboração da ontologia é a ontologia fundamental; ela é 1 . analítica do aí-ser e 2. analítica da Temporalidade 
uma analítica que ultrapassasse o carácter incompleto - porque meramente preparatório - de Ser e tempo, ficou por elaborar. Mas a pergunta pela ética não podia deixar de ficar suspensa das sugestões deixadas pela obra de 1927. Com efeito, esta apresenta já indícios suficientes das orientações que uma ética metaontológica poderia ter seguido. Seria então possível, a partir da análise de Ser e tempo, assim como das lições que o prepararam, tentar a reconstituição daquilo que a ética metaontológica, projectada no seguimento da ontologia fundamental, poderia ter vindo a ser. E, por outro lado, esta tarefa de reconstituição não poderia deixar de se interrogar acerca da razão pela qual a ética metaontológica não chegou a ser efectivamente elaborada. Tendo em conta que as análises metaontológicas que se seguiriam à completude da ontologia fundamental se deteriam especialmente una questão da ética», tal como as lições de 1928 permitem deduzir, torna-se legítimo perguntar que papel terá tido esta mesma questão no abandono da fase metaontológica do projecto da ontologia fundamental. Se um tal projecto se interrompe no momento em que seria legítimo esperar o aparecimento não apenas genericamente de análises metaontológicas, mas especificamente de uma ética metaontológica, não poderá esta interrupção estar ligada a problemas suscitados pela tentativa da sua elaboração? O presente estudo pode ser encarado justamente como um ensaio de resposta a esta pergunta.

O abandono do projecto de elaboração de uma ética metaontológica, frustrando as expectativas legitimadas pelas lições que se seguiram à publicação de Ser e tempo, coincide com aquilo a que, numa terminologia herdada de FriedrichWilhelm von Herrmann, podemos chamar a «mudança imanente» no pensamento heideggeriano. Uma tal mudança consiste na troca, para o acesso à questão do ser, da "via da ontologia fundamental" pela chamada "via da história do ser"". Esta é «imanente» porque é uma e a mesma questão que permanece na transição entre as duas vias. Torna-se então possível precisar a pergunta cuja resposta constitui o nosso tema. Se, de acordo com Heidegger, a questão do ser tem de ser posta a partir de duas vias diferentes, se é imanente à "via da ontologia fundamental" a necessidade de dar lugar a uma outra via de acesso a esta mesma questão, e se esta necessidade surge aquando da oportunidade de elaboração de uma ética, não estará a questão da ética relacionada com o abandono da "via da ontologia fundamental"? Por conseguinte, não estará a questão da ética relacionada com a emergência da "via da história do ser"? Por outras palavras: não poderemos distinguir a "via da ontologia fundamental" e a "vida da história do ser" justamente a partir das perspectivas éticas que sugerem ou explicitamente apresentam?

A resposta que aqui se sugere é a afirmativa. Com ela, não se pretende impor dogmaticamente uma interpretação única do percurso filosófico de Heidegger, mas apenas tentar hipoteticamente uma leitura deste percurso a partir de uma perspectiva temática que não é (ou pelo menos não é explicitamente) heideggeriana. Trata-se,

[Temporalität] do ser. Mas esta analítica temporal é, ao mesmo tempo, o giro [Kehre] em que a própria ontologia regressa explicitamente à ôntica metafísica, onde sempre implicitamente está» (GA26, p. 201).

1 Cf. Friedrich Wilhelm von HERRMANN, Wege ins Ereignis. Zu Heideggers «Beiträgen zur Philosophie», Frankfurt am Main, Vittorio Klostermann, 1994, p. 17. Aqui, a emergência da história do ser é descrita do seguinte modo: «Esta nova experiência pensante, que irrompe poderosamente, põe em movimento a inteira articulação da questão do ser colocada transcendental-horizontalmente. Este movimento é uma mudança imanente que apanha todas as questões postas até aí segundo a ontologia fundamental e as transporta, da via das questões transcendentais-horizontais, para a via das questões da história do Ser». 
no fundo, de inverter o modo como se encara naturalmente a filosofia de Heidegger a partir da publicação das Obras completas. Em vez de justificar o abandono da "via da ontologia fundamental" e, consequentemente, do projecto de elaboração de metaontologias - e especificamente de uma ética metaontológica - através da «mudança imanente» do pensamento heideggeriano, referindo que os trabalhos e estudos de Heidegger constituem essencialmente uma unidade, espraiada por caminhos que não se cristalizam em obras (segundo o lema heideggeriano: Wege, nicht Werke), o presente estudo procurará partir do carácter problemático da própria ética, para a partir daí conceber o caminho do pensar heideggeriano, na transição entre a ontologia fundamental e a história do ser que essencialmente o determina.

\section{A questão fundamental da ética: se e como a liberdade é possível}

Quando, na Carta sobre o. "humanismo", reflectindo sobre Ser e tempo, coloca explicitamente a questão da ética, Heidegger apressa-se a esclarecer que "antes de tentarmos determinar mais exactamente a relação entre "ontologia" e "ética", temos de perguntar o que são "a ontologia" e "a ética" elas mesmas»" ${ }^{12}$. Tal quer dizer que a ética que deveria ter sido desenvolvida no contexto de uma metaontologia fundada na ontologia fundamental não pode ser compreendida como uma ética o é na sua acepção corrente. No seu sentido mais imediato, dir-se-ia que a ética corresponde ao tratamento dado à questão formulada por Kant: "o que devo fazer?". Neste sentido, ela consiste na tentativa de encontrar, para usar os termos de Heidegger, «uma direcção vinculante» para a acção humana, assim como "regras que digam como o homem deve viver» ${ }^{13}$. Trata-se então de ordenar o "mundo" segundo o estabelecimento de uma hierarquia de valores, dirigindo eficazmente a acção de um sujeito que, sendo livre, está aquém desse mesmo "mundo" e, nessa medida, diante dos valores que o podem organizar, ordenar ou hierarquizar.

A elaboração de uma ética entendida como resposta à pergunta "o que devo fazer?" pressupõe então, segundo Heidegger, duas coisas. Em primeiro lugar, pressupõe a compreensão do homem como uma consciência que representa valores e que, nessa representação, se constitui como um sujeito situado aquém de um mundo de valores por ele representados. Em segundo lugar, pressupõe a compreensão do mundo como uma hierarquia de valores situada além do sujeito que a representa. Por outras palavras, uma tal ética implica uma exterioridade do mundo face a um sujeito que surge diante dele como uma consciência prévia e desvinculada. E, deste modo, a recusa heideggeriana em aceitar uma tal ética torna-se absolutamente compreensível: é justamente esta compreensão do homem e do mundo que, na sua ontologia fundamental, Heidegger pretende refutar. Daí que o ente humano, no modo de ser que lhe é essencial, seja determinado em Ser e tempo como ser-no-mundo: «O homem não "é", tendo, para além disso, ainda uma relação de ser com o "mundo" a que ele ocasionalmente se acrescenta. [...] Um tal estabelecimento de relações com o mundo só é possível porque o aí-ser é como é enquanto ser-no-mundo ${ }^{14}$.

Esta determinação da essência do homem tem justamente como intenção a ultrapassagem do subjectivismo de um sujeito posto diante do mundo como sua

12 Brief über den »Humanismus«, GA9, p. 353.

13 Idem, GA9, p. 353.

14 Martin HEIDEGGER, Sein und Zeit, Tübingen, Max Niemeyer, 1996, p. 57. 
consciência avaliadora. Assim, tendo em conta que «todo o avaliar é, mesmo quando avalia positivamente, um subjectivismo» ${ }^{15}$, a ética metaontológica, a ética que parte de uma analítica do ente humano como ser-no-mundo, longe de poder consistir na tematização da questão "o que devo fazer?", encontrando valores que lhe possam responder, não pode deixar de se caracterizar por um âmbito distinto dessa mesma tematização. Por outras palavras, ela consistirá numa ética mais originária, numa ética que se situe aquém da tarefa de avaliar.

A abordagem da ética no decurso da ontologia fundamental, ou seja, no decurso de uma filosofia que parte da determinação do homem como ser-no-mundo, e não como um sujeito cuja consciência seja prévia e subjacente ao próprio mundo, remete então para um sentido diferente da própria ética. Se o homem for encarado como um sujeito desvinculado, a pergunta "o que devo fazer?", e a ética enquanto desenvolvimento dessa pergunta, surge como uma inevitabilidade. Mas se o homem for determinado como ser-no-mundo, a questão da ética pergunta não pelo que o sujeito deve fazer, não pelos valores que devem orientar esse mesmo sujeito na sua acção à partida indeterminada, mas - mais originariamente - pela possibilidade do que naquela pergunta está implicitamente pressuposto. E o que nessa pergunta está pressuposto é a existência do homem como sujeito livre. Assim, se a ética que parte de um sujeito puro pergunta pelos valores capazes de orientarem a sua acção, pressupondo quer esse mesmo sujeito como desvinculado do mundo e, nessa medida, como livre, quer'a própria liberdade como indeterminação, a ética que parte do ser-no-mundo não pode deixar de perguntar previamente - naquilo a que aliás se poderia chamar uma ética fundamental - se e como a liberdade é possível. Longe de ser o ponto de partida nela pressuposto, a liberdade é justamente aquilo que numa ética baseada no ser-no-mundo não pode deixar de estar maximamente em questão.

Importa, no entanto, precisar o significado da liberdade que aqui está em causa. Antes de mais, é possível a sua determinação negativa. Ela não é a propriedade de um sujeito transcendental que, a partir de uma indeterminação essencial, procura encontrar valores que sirvam de critério determinante do seu agir. Ela não é a condição de possibilidade de um agir humano no mundo, a ratio essendi de uma moralidade que se constitui como a ratio cognoscendi que a manifesta. Ela não é o fundamento de um "dever", o fundamento possibilitante do Sollen que imediatamente se coloca na pergunta acerca de como orientar a própria acção. Pelo contrário, partindo da determinação do homem como ser-no-mundo, ela é justamente aquilo que um agir humano no mundo torna eminentemente problemático. Kant alude a este carácter problemático da liberdade ao determinar, para além da liberdade prática, a liberdade transcendental como «a faculdade de iniciar por si um estado» ${ }^{16}$. A liberdade por cuja possibilidade aqui se pergunta é então não simplesmente a condição de possibilidade de um "agir moral", mas de um "agir inaugural ou iniciador". Por outras palavras, ela refere-se não simplesmente a um pratein, mas a um arkhein ao carácter surpreendente e imprevisível de um inaugurar ou iniciar, em virtude do qual o homem se torna fonte exclusiva e, como tal, senhor (arkhontos) daquilo que se inaugura ou inicia. $O$ verbo grego arkhein fornece justamente o sentido da liberdade pela qual aqui se pergunta. arkhein é marcado pela irredutibilidade de um duplo significado: por um lado, o de iniciar ou inaugurar; por outro, o de ser senhor, de comandar. A liberdade pela qual se pergunta é então 
justamente esta possibilidade de ser senhor do seu agir, inaugurando ou, o que é o mesmo, abrindo (no sentido de uma Eröffnung) toda uma série de efeitos que, na medida em que decorrem dele, dele são essencialmente dependentes.

O carácter problemático da liberdade torna-se então claro. É certo que o homem, compreendido como ser-no-mundo, pode agir. Mas como é possível que o seu agir no mundo se constitua como um agir arquetípico, inicial ou inaugural? Como é possível que o mundo não elimine, na acção humana, a possibilidade do princípio e da inauguração? Como é possível a liberdade partindo da determinação do homem como ser-no-mundo? A elaboração de uma ética que parta destas questões resulta assim não na pergunta pelos critérios orientadores da acção, mas na pergunta pela possibilidade desta mesma acção enquanto inauguração. Por outras palavras, a ética metaontológica resultaria não numa axiologia, mas numa arqueologia da acção humana.

\section{A resposta de Ser e tempo à pergunta pela possibilidade da liberdade}

Embora a redacção de Ser e tempo corresponda apenas a uma analítica meramente preparatória do ente humano - a qual seria, nessa medida, inevitavelmente incompleta -, é possível encontrar nesta analítica os elementos necessários para a formulação de uma resposta à questão da ética, tal como ela foi apresentada. Uma tal questão consiste na pergunta pela possibilidade da liberdade. Partindo do homem como ser-no-mundo, Heidegger não poderia deixar de se interrogar, explícita ou implicitamente, como e se a liberdade deste mesmo homem é possível. E o modo como Ser e tempo responde a tal pergunta pode ser analisado em três passos, correspondentes ao tratamento que faz de três conceitos fundamentais da sua analítica da constituição ontológica do ente humano. Trata-se dos conceitos de estar-lançado (Geworfenheit), de decadência (Verfallen) e de inautenticidade (Uneigentlichkeit).

Num primeiro passo, dir-se-ia que a determinação do ente humano como um estar-lançado resulta directamente da consideração do seu ser como ser-no-mundo. Na medida em que é ser-no-mundo, o homem é o seu já estar lançado nesse mesmo mundo. E é-o não na figura de um passado, de uma Vergangenheit, de um lançamento que passou, mas de um sido que permanece sempre presente como determinação essencial do seu próprio ser, de uma Gewesenheit que permanece ainda uma forma de Wesen. Daí que o ente humano, na sua relação com o mundo, o não possa compreender puramente. Pelo contrário: na medida em que ele é o seu ter sido lançado no mundo, a sua compreensão do mundo nunca pode deixar de ser suportada por uma determinada disposição (Befindlichkeit). Como o próprio Heidegger esclarece: é certo que podemos compreender e dominar as nossas afecções e sentimentos. Mas, como não somos nada que esteja aquém do mundo, como a nossa essência consiste em já ter sido lançado no mundo, é também certo que «nunca nos tornamos senhores da nossa afecção sem afecção, mas sempre a partir de uma afecção contrária» ${ }^{17}$, ou seja, que "cada compreensão tem a sua afecção» ${ }^{18}$. A disposição, remetendo para o ter sido lançado que caracteriza o ente humano enquanto ser-no-mundo, implica então a facticidade deste mesmo ser-no-mundo. Deste modo, ela estabelece este ente, enquanto ter sido lançado no mundo, 
como já sempre fáctico. É ela que assinala neste ente o factum de "que ele é", tornando-lhe constitutivo o seu "aí" e determinando-o como um aí-ser: "a este "que ele é" chamamos o estar-lançado deste ente no seu aí, de tal modo que ele seja o aí como ser-no-mundo» ${ }^{19}$.

Num segundo passo, importa referir que se o ser-no-mundo consiste num ter sido já lançado no mundo, tal quer dizer que este corresponde a uma queda e, neste sentido, a uma decadência neste mesmo mundo. Esta decadência própria do ser-no-mundo não remete necessariamente para um estado originário, de cuja perfeição o homem possa ter caído: "A decadencialidade do aí-ser não pode ser concebida como "queda" de um "estado originário" mais puro e elevado» ${ }^{20}$. Supor um tal estado, seria conceber o ente humano como um ente "que está no mundo mas não é do mundo", como um ente que só acidental e temporariamente é o ser-no-mundo que o determina. Por outras palavras, seria perder a radicalidade que o ser-no-mundo, enquanto determinação da essência humana, procura assumir. Mas se o ente humano é já sempre facticamente ser-no-mundo, e se esta determinação, longe de ser uma mera característica negativa ou privativa, constitui uma determinação essencial, torna-se necessário perguntar em que sentido é possível falar do estar-lançado no mundo como uma decadência. A resposta de Heidegger é clara: «É dele mesmo enquanto ser-no-mundo fáctico que o aí-ser, enquanto decadente, já caiu» ${ }^{21}$. $\mathrm{O}$ conceito de decadência sugere então uma separação que se torna essencial clarificar: a separação entre o ente humano enquanto ele mesmo e o ente humano enquanto decadente e facticamente lançado no mundo. Por outras palavras, entre o ente humano no seu ser autêntico e a inautenticidade própria da decadência que à sua essência pertence.

Surgem assim, num terceiro passo, os conceitos de autenticidade e de inautenticidade enquanto modi fundamentais do ser-no-mundo. Se o ente humano é sempre ser-no-mundo, com a decadência própria de um ter sido sempre já lançado neste mesmo mundo, ele é sempre já não ele mesmo na sua autenticidade, mas apenas inautenticamente. O ser-no-mundo determina-lhe assim a inautenticidade como modus fundamental da sua existência. E, consequentemente, a autenticidade não tem o significado de um "modo de vida" alternativo à inautenticidade, mas apenas o de um «captar modificado desta»" ${ }^{22}$. Deste modo, Heidegger chega a uma formulação paradoxal da essência do ente humano. Por um lado, este ente é, na sua essência, ser-no-mundo, caracterizado pela decadência que lhe é própria. Por outro, esta essência não constitui o que este ente é autenticamente, determinando um modus pelo qual ele se furta à autenticidade do seu si mesmo. Por um lado, a essência do ente humano é ser-no-mundo. Por outro, o ser autêntico deste mesmo ente é justamente aquilo que pelo modus de ser que o ser-no-mundo estimula se vê contrariado.

A resposta de Heidegger à pergunta pela possibilidade da liberdade alicerça-se, em Ser e tempo, justamente nesta relação paradoxal. Dizer que o ente humano é, na sua essência, ser-no-mundo, significa dizer que ele não pode, enquanto humano, deixar de sê-lo. E dizer que esta essência determina no homem um modus. de ser inautêntico, significa dizer, por um lado, que a própria essência do homem lhe dificulta ser ele mesmo e, por outro, que ser autêntico consiste em resistir contra 
a tendência fomentada pela própria essência. Deste modo, a autenticidade pode, antes de mais, ser abordada negativamente: ela é aquilo contra o que o ser-no-mundo resiste. Mas esta abordagem negativa permite também um esboço positivo da própria autenticidade. Se a autenticidade consiste naquilo que o ser-no-mundo contraria, então ela consiste no contrário de ter sido lançado no mundo, de estar nele fechado. Ela é essencialmente a abertura e a liberdade que pelo lançamento e encerramento no mundo se vê contrariada. Autenticidade e liberdade são assim uma e a mesma coisa. Ser autêntico é então, na sua constituição, intrinsecamente abertura, projecção de possibilidades, numa liberdade a cada passo contrariada, limitada e, neste sentido, negada pela decadência do ser-no-mundo que a suporta.

Ao caracterizar a decadência (ou a inautenticidade) estimulada pelo ser-no-mundo do ente humano, Heidegger apresenta-a com três caracteríscas fundamentais. Ela corresponde, em primeiro lugar, à tranquilização pela qual o ente humano, imergindo no turbilhão do mundo que o envolve, não assume o esforço de ser autenticamente ele mesmo. Em segundo lugar, corresponde à alienação pela qual o ente humano, dispersando-se neste mesmo turbilhão, se esquece dele mesmo. Finalmente, em terceiro lugar, corresponde à tentação pela qual o ente humano se vê continuamente seduzido pelo mundo na sua constante novidade. É justamente nesta terceira característica que se pode encontrar o eixo em que assenta a relação entre homem e mundo: "O ser-no-mundo é, nele mesmo, tentador»" ${ }^{23}$. E é tendo em conta que o ser do homem, enquanto ser-no-mundo, é essencialmente tentação, determinando a vida humana, na sua facticidade, através da decadência, que, em Ser e tempo, a pergunta pela possibilidade da liberdade emerge. Será possível ao homem uma existência fáctica determinável como autêntica? E como é ela possível?

$\mathrm{Na}$ resposta de Ser e tempo a esta pergunta implícita, Heidegger começa por reforçar a caracterização do ser-no-mundo, enquanto inautenticidade e decadência, como a marca fundamental da essência humana. E esta marca assinala no homem duas determinações essenciais. Por um lado, determinado na sua essência como facticamente lançado num mundo, determinado na sua essência pela finitude própria desse estar-lançado, o homem é, enquanto ser-no-mundo finito, um ser para a morte. Por outro lado, determinado pela negatividade da finitude do ser para a morte, ele é, na sua essência, caracterizado por um ser-culpado fundamental. Na medida em que está lançado no mundo, na finitude de um ser para a morte, o homem é «enquanto tal, culpado» ${ }^{24}$. E Heidegger dá assim um primeiro passo na resposta à pergunta implícita sobre a possibilidade da liberdade. A liberdade, assim como a autenticidade que em si está contida, não consiste numa alternativa ao ser para a morte ou ao ser-culpado. Pelo contrário: a liberdade do ser para a morte não é possível como um salto para fora da finitude que enquanto tal o caracteriza, mas como uma sua configuração modificada. A liberdade possível consiste não em deixar de ser para a morte, mas em ser livremente para a morte ou, o que é o mesmo, numa «liberdade para a morte» ${ }^{25}$. Do mesmo modo, a autenticidade do ser-culpado não consiste num alívio da culpa, a qual pertence já sempre à decadência própria do ser-no-mundo, mas justamente numa culpa modificada por um «querer-ter-consciência» ${ }^{26}$ dessa mesma culpa. Se, em Ser e tempo, "o ser-culpado pertence ao ser do próprio aí-ser», se o "aí-ser "é" constantemente culpado», e se este ser- 
-culpado é a própria «possibilidade de ser autêntica ou inautenticamente culpado»" ${ }^{27}$, tal quer dizer que a autenticidade do homem, assim como a liberdade que se lhe associa, longe de corresponder a uma alternativa fáctica à inautenticidade, ou seja, a uma efectividade da liberdade, reduz-se apenas à modificação momentânea que se contém no instante da sua consciência angustiada.

A resposta heideggeriana à pergunta pela possibilidade da liberdade começa então por recusar a apresentação de um «ideal de existência "com conteúdo"» ${ }^{28}$. A "ética" consiste não em prescrever a orientação de uma acção que permita sair da decadência em que o ser-no-mundo enquanto tal está lançado, não em indicar ao homem como pode ser efectivamente livre, mas na consciência (no sentido de Gewissen) de que esta decadência determina o seu próprio ser e não pode, nessa medida, ser erradicada. O ser-no-mundo encerra em si uma culpa, uma finitude e uma negatividade inevitáveis. E a liberdade só é não enquanto alternativa a esta mesma negatividade, mas enquanto modus que tal negatividade pode momentaneamente assumir. Segundo Heidegger, a liberdade localiza-se então não no terreno de uma efectividade própria, mas no da efectividade da própria culpa e finitude do homem, de tal modo que a negatividade «pertence ao ser-livre» ${ }^{29}$. É certo que a culpa desperta no homem um apelo para que, diante de um mundo essencialmente tentador, e diante da culpa que a essa tentação pertence, este tome consciência do seu próprio ser enquanto ser-no-mundo e assuma a decadência que o constitui. $\mathrm{O}$ apelo, que «nunca é nem planeado por nós mesmos, nem preparado, nem executado voluntariamente ${ }^{30}$, corresponde à disposição angustiada pela qual o ente humano, num instante, se sente inquieto. É nesta inquietude (Unheimlichkeit) que o homem pode encontrar a sua autenticidade. Mas tal autenticidade, longe de corresponder a uma alternativa prática (e ética) à inautenticidade, enquanto modus sustentado pela essência do homem enquanto ser-no-mundo, corresponde apenas à consciência modificada desta mesma inautenticidade. Numa palavra, em Ser e tempo, ser autêntico é não libertar-se da culpa própria da decadência e da inautenticidade, de que não há libertação possível, mas apenas captar esta mesma culpa no instante silencioso de uma angústia consciente.

\section{A "ética" possível a partir de Ser e tempo}

O carácter fundamental daquilo que seria uma "ética" a partir de Ser e tempo pode ser assim suficientemente circunscrito. O ser-no-mundo traduz a exposição do homem a uma constante tentação. Determinada como um ter sido lançado no mundo, a "vida humana", a existência (enquanto ser-no-mundo e ser para a morte) consiste no ser-culpado próprio de uma decadência. E, diante desta culpa, surge no homem o apelo para uma consciência angustiada da tentação dispersante que a constitui. Não se trata então de estabelecer um quadro de valores edificantes, capaz de construir e consolidar um agir segundo o conteúdo de um "ideal de existência". Não se trata de fundamentar um "modo de vida" ou uma prática capaz de escapar à facticidade de uma existência dispersa no mundo. Trata-se apenas de decidir, num instante de lucidez sem continuação, ir contra uma maré cujo fluxo não cessa, numa decisão que a cada passo carece de ser repetida. 
Ao longo das lições que prepararam Ser e tempo, sobretudo ao longo das lições do primeiro período de Freiburg, Heidegger põe a claro as raízes que determinam a sua analítica existencial e, com ela, a "ética" a que esta implicitamente faz alusão. Trata-se de uma análise do ente humano herdada sobretudo de uma confrontação directa com o pensamento augustiniano. É aliás nas lições lidas em Freiburg do Semestre de Inverno de 1921, intituladas precisamente Agostinho e o platonismo, que Heidegger expõe mais claramente a concepção da "vida humana" ou, o que aqui é o mesmo, da existência enquanto ser-no-mundo como tentatio. E é dela que se retira a difícil exigência de responder permanentemente a uma tentação constante. A vida é, nesta perspectiva, um constante desafio. E a exigência ética a que o homem se expõe consiste em permanentemente tentar superá-lo, apesar da queda cuja possibilidade se esconde a cada passo. Em notas que servem de apêndice às referidas lições, a estrutura dual da "ética" heideggeriana de Ser e tempo é pela primeira vez esquematicamente esboçada: $" V i t a=$ tentatio. Experimentar a tentatio - "aguentar-se", "cair" $\rangle^{31}$. Num mundo que é essencialmente tentador e dispersante, numa vida que é essencialmente decadência, tratava-se não de efectivar um modo de agir que contornasse a decadência, mas de assumi-la, num instante de angústia, de um modo modificado. Tratava-se não de escapar à culpa, mas de ser-culpado de um modo decidido e consciente.

Se o esboço da "ética" a que Ser e tempo implicitamente alude se torna claro sobretudo a partir de uma confrontação explícita com o pensamento augustiniano, patente ao longo das lições dos anos 20 , é o contexto desta confrontação que the atribui o seu verdadeiro significado. Um tal contexto surge à luz daquilo a que, sobretudo a partir dos estudos de Max Weber, se poderia chamar a distinção entre as éticas católica e protestante. É já em 1905 que Max Weber publica $A$ ética protestante e o espirito do capitalismo, assinalando, como centro da espiritualidade protestante, a doutrina calvinista da predestinação. Segundo Weber, esta doutrina inspiraria uma ética que importa reter. Se desde sempre os homens estavam ou salvos ou condenados, a vida mundana do homem não seria, na perspectiva protestante, senão o percurso através do qual, mediante uma santidade coerente, caracterizada por uma prosperidade crescente desenvolvida na dependência desta mesma santidade, o eleito de Deus mostrava que o era. A vida e as obras eram eficazes não para produzir a salvação, mas para a tornar visível. E, deste modo, toda a ética protestante assentava não na consideração de acções singulares, mas na construção de uma vida coerente e próspera ao longo do tempo. Para o protestantismo calvinista, usando os próprios termos de Weber, "Deus não exigia dos seus "boas obras" singulares, mas uma santidade nas obras que se erguesse como sistema» ${ }^{32}$. E se a vida consistia num percurso coerente e sistemático de santidade, o mundo caracterizava-se não como a sede perigosa da tentação, mas como o palco onde a salvação ganhava a visibilidade que a tornava certa e segura.

A posição de Weber sobre o carácter específico do protestantismo esteve longe de ser pacificamente aceite. Werner Sombart, por exemplo, recusa ao protestantismo o monopólio daquilo a que poderíamos chamar uma "ética da vida sistemática", tentando reconhecer já num âmbito prévio ao protestantismo as características que propiciaram o aparecimento de uma sistematicidade, coerência e

32 Max WEBER, Die protestantische Ethikund der Geist des Kapitalismus, Gesammelte Aufsätze zur Religionssoziologie, ed. Mariane Weber, Tübingen, 1920, Vol. I, p. 114 (Obra reproduzida em ediçã̃o CD-Rom: Max Weber im Kontext, Wissenschaftliche Buchgesellschaft, 1999). 
prosperidade da vida. Mas autores católicos como Carl Schmitt ${ }^{33}$ assumiram a perspectiva de Weber, procurando distinguir no catolicismo o contrário da ética protestante weberiana. Na sua autointerpretação, o catolicismo começava então a identificar-se através da contraposição a esta mesma ética. O mundo é, para este catolicismo, não o palco da manifestação da salvação divina, mas a sede da dispersão e da tentação, um complexio oppositorum impossível de sistematizar, cuja ordem falível e precária, longe de ser imanente, não pode deixar de ser instituída a partir da autoridade exterior de uma decisão. E a vida, por seu lado, é constituída por um conjunto de instantes, em si mesmos sem continuidade, impossíveis de se reduzirem à unidade de um sistema. Para um tal catolicismo romano, contraposto ao protestantismo na sua organização de uma vida sistemática, calculável e previsível, no seu culto do progresso e da prosperidade no seio de um mundo "desencantado", a salvação ou a perdição poderiam surgir "como um ladrão na noite", irrompendo num instante em que se poderia jogar o destino eterno de uma vida.

A "ética" esboçada por Heidegger em Ser e tempo adquire então aqui o contexto que lhe dá o seu máximo significado. Na sua confrontação com o pensamento augustiniano, Heidegger apresenta os fundamentos de uma "ética" que, herdando o "espírito do catolicismo", se contrapõe frontalmente à ética protestante caracterizada por Weber. À vida considerada como um percurso coerente e sistemático, ao mundo considerado como palco patenteador da salvação, opõe-se um mundo e uma vida cuja tentação constitutiva exige a cada passo a decisão. E à ética entendida como uma filosofia expositora de valores por cuja observação se mostrava a santidade, opõe-se uma "ética" do instante da decisão, uma "ética" em que a salvação se pode jogar num instante sem continuidade e em que, consequentemente, a acção humana no mundo não pode eliminar nem diminuir a tentação, o eminente perigo, que constitui esse mesmo mundo.

\section{A insuficiência da resposta de Ser e tempo: a pergunta pela possibilidade da} liberdade enquanto pergunta por um ideal fáctico de uma existência autêntica

O esboço de uma "ética" decorrente da confrontação com o pensamento augustiniano, nos termos em que ocorre em Ser e tempo, arrasta consigo um carácter problemático que importa explicitar. Uma tal "ética" surgia como resposta à pergunta implícita sobre se e como a liberdade seria possível. E, considerando esta pergunta implícita, tendo em conta que o ser-no-mundo traduzia a exposição do ente humano a uma tentação constante, marcando a sua existência fáctica com o modus da decadência e da inautenticidade, tornava-se necessário voltar a colocar a questão acerca da possibilidade da liberdade. Se o ente humano é, na sua essência, ser-no-mundo, e se o ser-no-mundo se traduz facticamente num modus inautêntico de ser, como é possível que o ente humano exista autenticamente? Não será a inautenticidade um modus permanente do ente humano?

Em Ser e tempo, Heidegger é explícito quanto à possibilidade de a inautenticidade ser contrariada pela autenticidade: «A inautenticidade tem por fundamento uma autenticidade possível. A inautenticidade caracteriza um tipo de ser em que o aí-ser se pode extraviar e também sempre, na maioria das vezes, se extraviou, mas

33 Cf. Carl Schmitt, Catolicismo romano e forma politica, trad. Alexandre Franco de Sá, Lisboa, Hugin, 1998. O texto é de 1923, tendo sido ligeiramente alterado na sua segunda edição, publicada em 1925. 
em que não tem de se extraviar necessária e constantemente» ${ }^{34}$. Contudo, embora Heidegger assegure claramente que a inautenticidade não é nem necessária nem constante, a própria formulação em que o faz não pode deixar de suscitar um regresso do problema da possibilidade da liberdade, perguntando-se pela possibilidade de uma autenticidade situada num plano diferente. Neste plano, pergunta-se não apenas pelo carácter não permanente da inautenticidade, vislumbrando a autenticidade como possível, mas também, para além disso, pela possibilidade de a autenticidade poder tornar-se ela mesma permanente, marcando aquilo a que se poderia chamar um "modo de vida", uma existência fáctica caracterizável como autêntica. A questão da ética torna-se assim no problema de saber em que medida a autenticidade pode encontrar na existência humana um abrigo onde possa permanecer e habitar, uma morada onde se possa acolher e demorar, ou seja, numa palavra, um êthos. Uma "ética" que encarasse a existência humana como uma corrente marcada pela inautenticidade, interrompida apenas por um instante angustiado sem continuidade, seria, ao limite, uma "ética" impotente. E, se assim fosse, ela apenas o seria na aparência. A questão ética acerca da possibilidade da liberdade adquire então, à luz deste problema implícito, uma reconfiguração que é fundamental explicitar. Ela pergunta não apenas se a decisão contra a tentação é possível, mas se esta decisão pode permanecer na "vida do homem", se ela pode habitar a sua existência, residindo e enraizando-se nela, encontrando nela um êthos que lhe sirva de abrigo e morada, ou seja, criando nela raízes e possibilitando ao homem uma existência fáctica alternativa à decadência e à inautenticidade.

A pergunta pela possibilidade fáctica da autenticidade, entendida como um "modo de vida" possível e não como o instante sem continuidade de uma consciência angustiada, está já implícita de um modo suficientemente claro em Ser e tempo. Daí que, mesmo recusando explicitamente a exposição de um «ideal de existência "com conteúdo"» ${ }^{35}$, Heidegger não possa deixar de insistir na pergunta, acabando por reconhecer que na sua análise está subjacente «uma concepção ôntica determinada da existência autêntica, um ideal fáctico do aí-ser» ${ }^{36}$. É certo que este "ideal fáctico" da existência não se poderia confundir com um «ideal de existência vazio $\rangle^{37}$, próprio da tentativa moralizante de encontrar, para um sujeito transcendental concebido como situado aquém do mundo, valores que pudessem servir de norma universal de conduta. Contudo, a diferença face a esta tentativa consistia não na necessidade de um ideal, ou seja, na necessidade de encontrar a referência a uma possível concretização da autenticidade, mas no conteúdo que esse mesmo ideal deveria assumir. Tratava-se da constituição de um ideal que, longe de se adequar à universalidade vazia de um sujeito situado fora do mundo, resultava do ser próprio do homem enquanto ser-no-mundo.

É já em Ser e tempo que, apesar de toldado pelo matiz augustiniano da análise, o esboço da autenticidade enquanto "ideal fáctico" começa a ganhar forma. Heidegger determinava aqui o ser autêntico do homem como um "ser-culpado autêntico" ou uma "liberdade para a morte". Mas, diante da autenticidade desta "liberdade para a morte", a pergunta pela possibilidade da liberdade não poderia deixar de regressar, interrogando-se agora sobre a possibilidade de a fazer corresponder a uma efectividade ou concreção. Deste modo, apesar do peso da 
inautenticidade e da decadência na constituição ontológica do humano, a pergunta pela possibilidade da liberdade, em Ser e tempo, não pode deixar de aparecer reformulada: se o homem é, enquanto aí-ser, um ser-no-mundo lançado para a morte, «será que o aí-ser se lança facticamente num tal ser para a morte?» ${ }^{38}$. Perguntando de outro modo: se a liberdade é possível como uma liberdade para a morte, que significa isso "na prática"? Como se pode fáctica ou concretamente ser para a morte? Como se pode fáctica ou concretamente ser livre? Eis a configuração que a questão da possibilidade da liberdade, mesmo já em Ser e tempo, não pode deixar de adquirir. E a resposta poderia ser antecipada a partir da simples consideração da pergunta. Se o ente humano é, na sua essência, ser-no-mundo e, enquanto ser-no-mundo, um ser finito para a morte, a autenticidade do homem, enquanto "ser livre para a morte" ou enquanto "estar-lançado livremente no mundo", não poderia deixar de estar na assunção da situação em que a sua facticidade o enraiza, assim como na preparação para a morte que esta mesma assunção traz consigo.

Já em 1927, em Ser e tempo, Heidegger podia caracterizar a autenticidade, na decisão que esta exige, como aquilo que traz «o ser do aí à existência da sua situação " $^{39}$. E tal caracterização correspondia à aproximação da autenticidade à figura de um "ideal fáctico de existência". Se o homem, enquanto ser-no-mundo, se encontrava como uma liberdade finita inserida numa situação fáctica partilhada com outros no contexto de uma comunidade, a autenticidade consistia num modo de vida que assumisse a sua finitude e a situação que a caracterizava. Ser autêntico correspondia assim a compreender-se «livre para a morte, na supremacia própria da sua liberdade finita, para nela, que só "é" de cada vez no ter-escolhido da escolha, assumir a impotência de estar entregue a si mesmo e tornar-se clarividente para as contingências da situação que está aberta ${ }^{40}$. Os termos supremacia e impotência, respectivamente Übermacht e Ohnmacht, um "sobre-poder" e um "sem-poder", traduzem justamente o modo como se pode ser autenticamente ser-no-mundo: lançado numa situação fáctica, o homem terá de assumir a sua determinação pelo poder dessa situação, terá de assumir uma tal determinação como um poder incontestável, como uma Übermacht, encontrando a sua liberdade nessa assunção, ou seja, na impotência própria, na Ohnmacht, para recusar esta mesma determinação. Concretamente, ser autêntico corresponde a aceitar uma situação que a sua finitude lhe oferecia como destino, assumindo decididamente tal destino como seu. Corresponde, por outras palavras, a assumir como sua a sua situação no espaço e no tempo, determinando-se como um herdeiro pertencente ao espaço de um povo ou comunidade e ao tempo de uma geração: «Se o aí-ser que tem um fado, enquanto ser-no-mundo, existe essencialmente no ser-com com outros, o seu acontecer é um acontecer-com e determina-se como destino. Assinalamos assim o acontecer da comunidade, do povo. [...] O destino do aí-ser que tem um fado na e com a sua "geração" constitui o acontecer pleno e autêntico do aí-ser»" ${ }^{41}$ É assim que, se «só na partilha e no combate é que o poder do destino se liberta» ${ }^{42}$, e se a autenticidade consistia justamente na assunção deste destino como herança, Heidegger pode falar, já em Ser e tempo, de «possibilidades fácticas de um existir autêntico a partir da herança» ${ }^{43}$. 
Embora o esboço da autenticidade enquanto "ideal fáctico" seja, em Ser e tempo, sempre tímido, toldado pela análise de um ser-no-mundo que determina no homem a sua decadência, ele tornar-se-á, a partir sobretudo dos anos 30, explicitamente assumido. E esta assunção corresponde ao estabelecimento do conteúdo de uma ética no seguimento das análises preparatórias da ontologia fundamental ou, o que é o mesmo, de uma ética metaontológica. Nas suas lições do Semestre de Inverno de 1929-1930, intituladas Os conceitos fundamentais da metafisica. Mundo - finitude - solidão, Heidegger pode concretizar o significado desta decisão para a situação enquanto ideal fáctico da existência humana. A autenticidade é aqui ainda caracterizada como possível apenas num instante. Mas este instante - e este é o ponto decisivo - tem agora uma continuidade, marca um "modo de vida" e, deste modo, determina uma acção e as suas consequências. Daí que a inautenticidade se traduza, nestas lições, em reprimir a aflição, as carências, «de tal modo que ninguém esteja com o outro, e nenhuma comunidade esteja com a outra, na unidade enraizadora de um agir essencial $\rangle^{44}$. A existência enquanto ser-aí (Da-sein) traduzia o peso do enraizamento no "aí" de uma situação, assim como nas carências que desta situação fazem parte, peso esse que um "modo de vida" inautêntico tenta a todo o custo aliviar: «Não são apenas indivíduos, mas grupos, ligas, círculos, classes, partidos - tudo e todos estão organizados contra as carências, e cada organização tem o seu programa» ${ }^{45}$. E, diante da ligeireza anestesiante de todas estas organizações, surge a exigência de despertar «a mais intima necessidade da liberdade do aí-ser ${ }^{46}$, assumindo tal liberdade justamente como uma recusa da ligeireza e uma aceitação do peso que o "aí" da sua situação constitui. Trata-se da exigência de «libertar a essência do homem, isto é, de deixar vir a ser nele essencialmente o ai-ser $\rangle^{47}$. E Heidegger pode agora remeter abertamente para o "modo de vida" que tal libertação representa: «Esta libertação do aí-ser no homem não quer dizer colocá-lo num arbítrio, mas carregar o homem com o ai-ser como o seu fardo mais próprio. Só quem pode verdadeiramente dar a si mesmo um fardo, é livre» ${ }^{48}$.

Ao longo dos anos 30 , a configuração da autenticidade como "ideal fáctico de existência" torna-se cada vez mais notória. Tratava-se sobretudo da oposição ao "modo de vida" liberal, próprio de um sujeito compreendido como um eu puro ou, o que é o mesmo, como uma consciência desvinculada. E, numa Alemanha que via o liberalismo de Weimar afundar-se politicamente, o "ideal fáctico" de uma vida decidida à assunção da situação podia ser elaborado de um modo cada vez mais concreto. É justamente no contexto da agonia da República de Weimar e da emergência do nacional-socialismo que a configuração da autenticidade, enquanto "ideal fáctico" da existência humana, atinge o plano da acção concreta. A 11 de Novembro de 1933, num discurso de apoio a Hitler na saída da Alemanha da Sociedade das Nações, Heidegger escrevia que «de agora em diante, todas as coisas exigem decisão e todo o fazer responsabilidade ${ }^{49}$, cabendo a cada um assumir o seu povo, decidindo-se para a situação que o constitui: «A nossa vontade de uma auto-responsabilização popular [völkisch] é que cada povo encontre e guarde a 
grandeza e a verdade da sua determinação. [...] O guia [Führer] despertou plenamente esta vontade no povo inteiro e soldou-a numa única decisão. Nenhum de nós pode ficar afastado no dia da manifestação desta vontade ${ }^{50}$.

A decisão para a situação, que, em Ser e tempo, dificilmente se poderia ver facticamente concretizada, ganha agora um aspecto plenanente concreto. E este aspecto é configurado sobretudo através da meditação sobre o livro O trabalhador de Ernst Jünger, aparecido em 1932. Nele, Jünger opunha ao homem liberal aquilo a que chamava a "figura típica do trabalhador". O homem liberal consistia num sujeito puro; no romântico que descobria no fascínio por terras longínquas e tempos passados a possibilidade de fuga diante da sua situação ${ }^{51}$; no cosmopolita que recusava o seu povo e a sua geração ${ }^{52}$; no burguês que, desejoso de segurança, procurava furtar-se à possibilidade da guerra num diálogo constante e indefinido ${ }^{53}$, contendo a própria vida nos limites estreitos de uma racionalidade económica, de uma «imagem ideal racional-virtuosa do mundo» ${ }^{54}$. Numa palavra, o homem liberal consistia num sujeito essencialmente livre, cuja liberdade se caracterizava essencialmente como indeterminação e desvinculação. E a figura do trabalhador, que Jünger assinala através de um "realismo heróico", contrapunha-se justamente a esta liberdade desvinculada, remetendo para uma outra liberdade constituída pela liberdade de participar, de se comprometer e de se vincular. Por outras palavras, Jünger opusera a uma "liberdade liberal", a uma liberdade desvinculada, padronizada e sem conteúdo, uma liberdade mais autêntica e genuína que se assumia como vínculo e, nessa medida, como serviço ${ }^{55}$. E o trabalhador era justamente o homem que encontrava a liberdade autêntica no trabalho, no serviço e no vínculo. É então nesta liberdade do trabalhador jüngeriano que Heidegger encontrará a ocasião para uma tematização da autenticidade segundo um aspecto concreto.

Nas lições do Semestre de Verão de 1934, intituladas Lógica enquanto pergunta pela essência da linguagem, lidas por Heidegger logo após o seu abandono do reitorado, o estar-lançado no mundo, no seu ter-sido (Gewesenheit), toma a forma de uma destinação determinada como tradição (Überlieferung) ${ }^{56}$. O futuro, as possibilidades que o aí-ser autêntico tem para assumir são agora, nestas lições, um encargo (Auftrag) e uma missão (Sendung) marcados por uma destinação ou determinação (Bestimmung) essencial. E a sua articulação, a assunção da tradição como determinação de um encargo e de uma missão, a assunção do seu lançamento

50 GA16, p. 193.

s1 Cf. Ernst JÜNGER, O trabalhador, trad. Alexandre Franco de Sá, Lisboa, Hugin, 2000, p. 102: «A multiplicidade de tempos passados e de espaços longínquos impõe-se como uma orquestra variada e sedutora, com a qual uma vida enfraquecida nada consegue orquestrar senão a própria fraqueza».

s2 Cf. Idem, p. 235: «Enquanto, do lado do espírito cosmopolita, se procura canonizar a traição à pátria, o lado sangrento da vida gera uma justiça secreta, que trabalha com boicotes, atentados e tribunais clandestinos».

53 Cf. idem, p. 77: «O burguês, pelo contrário, deve ser concebido como o homem que reconhece a segurança como um valor supremo e que determina a condução da sua vida de acordo com isso».

54 Idem, p. 61.

55 Idem, pp. 50: «Pois nesta terra [na Alemanha] é irrealizável um conceito de liberdade que se deixe aplicar a qualquer grandeza que lhe seja submetida, como uma medida fixa e em si mesma carente de conteúdo. Em vez disso, aqui foi válido desde sempre o seguinte: que a medida da liberdade de que uma força dispõe corresponde exactamente à medida do vínculo que lhe está reservado».

s6 Cf. GA38, p. 117. 
no mundo como uma exigência de serviço e vínculo, é conseguida precisamente através do trabalho. Deste modo, no seguimento da tematização jüngeriana da figura do trabalhador, Heidegger representa no trabalho o aspecto concreto da autenticidade, de uma autenticidade que, enquanto assunção pelo homem do seu ser enquanto ser-no-mundo, adquire a configuração de um ideal de serviço e vínculo: o vínculo à determinação da sua situação e a disponibilidade para o serviço e para as tarefas que esta situação exige. Daí que Heidegger possa assinalar «o poder que rege o nosso ser enquanto ser histórico» como «trabalho do homem - trabalho não como uma ocupação qualquer, mas como o cumprimento da cunhagem e a disposição daquilo que, na obra, se nos coloca como tarefa no nosso aí-ser histórico ${ }^{57}$. O trabalho é então aqui a assunção da situação do ser-no-mundo, do poder que rege o homem, sob a forma concreta de um agir. E a obra, a efectividade que resulta do cumprimento de uma tarefa assumida como trabalho, é justamente o resultado da concretização desta assunção.

Para Heidegger, sob a influência de Jünger, o trabalhador erguia-se como aquele que, trabalhando, encontrava no seu sacrificio ao próprio trabalho (a um trabalho entendido como encargo e missão) o sentido da sua elevação a uma existência mais elevada e autêntica. No discurso de assunção do reitorado, intitulado A auto-afirmação da universidade alemã, articulando aquilo a que chama os três serviços que vinculariam o estudante alemão - o seviço de trabalho, o serviço militar e o seviço do saber -, Heidegger pode justamente falar da liberdade enquanto ideal fáctico de seviço e vínculo: «A tão louvada "liberdade académica" é expulsa da universidade alemã; pois esta liberdade não era genuína, porque era apenas negadora. [...] O conceito de liberdade do estudante alemão é agora trazido à sua verdade. É a partir dele que futuramente se desenrolam o vínculo e o serviço dos estudantes alemães» ${ }^{58}$. A liberdade, na autenticidade que lhe é própria, surge como concreta enquanto vínculo, serviço ou trabalho. E o serviço de trabalho, o primeiro dos três serviços mencionados por Heidegger, torna-se então no arquétipo de todo e qualquer agir livre e autêntico do ser-no-mundo. Neste sentido, tanto o serviço militar como o serviço de saber são modos que um agir marcado pela autenticidade, ou seja, modos que um agir que seja determinado como trabalho, modos que um serviço de trabalho, pode assumir.

É neste sentido que pode ser compreendido o discurso que, a 25 de Novembro de 1933, na sequência do discurso de assunção do reitorado e na qualidade de reitor, Heidegger dirige aos estudantes da Universidade de Freiburg. Um tal discurso intitula-se precisamente $O$ estudante alemão como trabalhador. Nele, Heidegger afirma que «o estudante que foi até agora só é trabalhador porque e na medida em que "estuda". Mas o novo estudante "estuda" porque é trabalhador»" ${ }^{59}$. Ou seja, o seu "serviço de saber" constitui um modo possível de "serviço de trabalho", um modo possível de assunção da sua situação, um modo possível de cumprir o encargo e a missão que a tradição lhe destina como determinação. Se o trabalho significa a decisão para o serviço, a decisão para a assunção do fardo da existência enquanto aí-ser, então o "ideal fáctico" da decisão para a situação surgia concretizado explicitamente como um ideal de trabalho, como o ideal de uma decisão para uma acção de serviço. Deste modo, o ideal fáctico da existência pode finalmente

57 GA38, p. 134.

58. Die Selbstbehauptung der deutschen Universität. Das Rektorat 1933/34, Frankfurt am Main, Vittorio Klostermann, 1990, p. 15.

59 GA16, p. 206.

60 GA16, p. 207. 
configurar-se claramente como um ideal de acção, como um ideal de efectivação de uma obra e, nessa medida, como uma ética: «Cada decisão genuína transfere-se para a imediatidade do agir dentro de uma situação e de um ambiente determinados $\rangle^{60}$.

Por outro lado, se o "serviço do saber" constituía uma possibilidade do "serviço de trabalho", concretizando o "ideal fáctico" de uma decisão para a situação, também o "serviço militar" pode concretizar esta mesma decisão, encarada agora especificamente sob a forma da assunção do próprio aí-ser como ser para a morte. É nas lições do Semestre de Inverno de 1934-35, intituladas Os hinos de Hölderlin "Germânia" e "O Reno", que Heidegger aborda esta concretização, num passo cuja inequivocidade não pode deixar de ser surpreendente: «A camaradagem dos soldados da frente não tem o seu fundamento nem em ter-se de estar junto porque faltam outros homens, de quem se está longe, nem também em entrar-se num entusiasmo comum, mas, no mais profundo e singular, em a proximidade da morte como sacrifício pôr cada um em igual nulidade, de tal modo que esta se tornou a fonte de uma pertença mútua incondicional. É justamente a morte, que cada homem singular tem de morrer por si, que singulariza cada singular consigo da forma mais extrema, é justamente a morte e a preparação para o seu sacrifício que cria o espaço da comunidade do qual brota a camaradagem $\rangle^{61}$. Do mesmo modo que a decisão para a situação, o ser para a morte, na angústia que o constitui, adquire o aspecto concreto de um serviço, sob a forma de uma prontificação para o sacrifício próprio. Nele ressoa claramente, mais uma vez, a descrição por Jünger do homem que, na figura do trabalhador, "descobre ao mesmo tempo a sua determinação, o seu destino», tornando-se "capaz do sacrificio que ganha no sacrificio de sangue a sua expressão mais significativa» ${ }^{62}$.

Contudo, se, nos anos 30, a autenticidade era apresentada abertamente como um "ideal fáctico" concretizável numa ética, numa acção, num êthos ou, o que é o mesmo, em "modos de vida" possíveis, os termos em que esta era elaborada por Ser e tempo, não o esqueçamos, embora a sua analítica preparatória do ente humano manifestasse já uma propensão para tal apresentação, não podiam deixar de marcá-la com um outro sentido. Como já fieou sufieientemente demonstrado, o tratamento da autenticidade em Ser e tempo dificilmente daria lugar a uma ética genuína. A "ética" de Ser e tempo consiste não propriamente em ser autêntico, mas em ter uma consciência modificada (e, neste sentido, autêntica) da inautenticidade e decadência que a própria existência, a própria "vida" humana, determinada como ter sido lançado no mundo, em si mesma encerra. Ela assentava essencialmente na equação augustiniana da "vita = tentatio tota", elaborada explicitamente por Heidegger sobretudo ao longo das lições do primeiro período de Freiburg e nunca abandonada até à redacção de Ser e tempo.

A angústia, a disposição conducente à possibilidade de uma decisão autêntica, é então marcada, em Ser e tempo, devido ao "predomínio da decadência», por uma «raridade fáctica» ${ }^{63}$. E esta raridade fáctica tem como consequência que o homem, longe de poder determinar a sua facticidade através de um "modo de vida" autêntico, cumprindo a exigência implícita numa ética, não possa senão ter uma consciência autêntica de que esta mesma autenticidade, enquanto alternativa à inautenticidade, é facticamente impossível. Daí que, em $O$ que é a metafisica?, directamente na sequência de Ser e tempo, Heidegger possa escrever que a angústia, e a 
autenticidade por ela aberta, sucede «só por instantes» ${ }^{64}$, fechando assim a possibilidade de esta mesma autenticidade adquirir o enraizamento e a continuidade que lhe permita determinar uma vida humana. Por outras palavras, a autenticidade, em Ser e tempo, é certamente possivel num instante angustiado de consciência modificada. Mas não o é - e é este o aspecto que aqui interessa destacar - nem na vida humana, nem na acção do homem que nessa vida tem lugar. Em Ser e tempo, Heidegger não permite a mínima dúvida sobre a exclusão da autenticidade em relação a um agir fáctico: «Necessariamente, todo o agir é facticamente "sem consciência" $\rangle^{65}$. A elaboração de uma ética a partir de Ser e tempo seria então, apesar da propensão que a obra manifesta, uma tarefa impossível.

Heidegger vê-se então diante de uma encruzilhada. Por um lado, a influência augustiniana em Ser e tempo não permite a consideração da autenticidade como um "ideal" ou, o que é o mesmo, como a referência de um "modo de vida" alternativo à inautenticidade. Por outro lado, o projecto de elaboração de uma ética metaontológica, na continuação do estabelecimento de uma ontologia fundamental, tornava o aparecimento desta alternativa à inautenticidade uma exigência incontornável. Deste modo, o próprio projecto de continuação da ontologia fundamental, através da elaboração de uma ética metaontológica, impunha a necessidade de uma revisão da analítica que o preparava, procedendo a uma reelaboração das características da autenticidade - a angústia e a decisão - de modo a torná-las compatíveis com uma efectiva possibilidade fáctica, com um êthos. Tornava-se então imprescindível não apenas reelaborar a analítica do ente humano esboçada de um modo apenas preparatório em Ser e tempo, mas reelaborá-la tendo em conta a necessidade de abrir a possibilidade de uma ética traduzida numa existência fáctica do homem caracterizável como autêntica.

Deste modo é necessário colocar explicitamente duas questões, por cuja consideração se poderá encarar o modo como, no seguimento de Ser e tempo, Heidegger tenta possibilitar a elaboração de uma ética. Em primeiro lugar, é preciso voltàr a considerar a analítica preparatória da existência do homem em Ser e tempo, para, confrontando-a com o seu tratamento nos textos que imediatamente the sucedem, perguntar por aquilo que nesta mesma analítica é alterado. Em segundo lugar, e partindo do conteúdo desta alteração, torna-se necessário perguntar de que modo esta propicia o aparecimento da autenticidade concebida como a possibilidade de uma vida fáctica alternativa à decadência, possibilitando, consequentemente, a emergência de uma ética.

\section{A possibilidade do "ideal fáctico" através da radicalização da finitude: a passa- gem para a história do ser}

Heidegger volta a considerar a sua analítica da existência do ente humano entre 1927 e 1929, anos que medeiam a publicação de Ser e tempo e de Kant e o problema da metafisica. Em Ser e tempo, como se disse, o ente humano aparece determinado, na sua essência, como uma liberdade finita, como uma abertura já lançada num contexto que a circunscreve e finitiza. O ser-no-mundo determina o homem como já sempre lançado na dispersão de um mundo sempre tentador. E o seu ser autêntico consiste não na dispersão desse mesmo ser-no-mundo, mas na 
liberdade que por tal dispersão é sempre contrariada. Deste modo, o homem é, no seu núcleo mais essencial, a abertura de uma liberdade, a qual se encontra sempre finitizada pela situação que a enraiza. É justamente este núcleo mais essencial que, ao voltar a considerar a analítica preparatória da existência humana, Heidegger irá alterar. Uma tal alteração não consiste no abandono da analítica da existência de Ser e tempo, mas apenas na sua reelaboração através daquilo a que se poderia chamar, para usar a expressão sugerida por Jean Grondin, uma «radicalização filosófica da finitude ${ }^{66}$. Se, em Ser e tempo, o núcleo mais essencial do ser-no-mundo consistia na abertura e na liberdade, surgindo a finitude que lhe era cooriginária apenas como a finitização dessa mesma liberdade, é a finitude que, a partir da publicação de Ser e tempo, conquista gradualmente o primado na determinação desse núcleo mais essencial. Em Kant e o problema da metafisica, a finitude adquire justamente o estatuto de núcleo mais fundamental da existência. Aqui, a finitude aparece como o mais íntimo fundamento da existência humana. Esta é «em si, como tipo de ser, finitude» ${ }^{67}$, de tal modo que «mais originário que o homem é a finitude do aí-ser nele» ${ }^{68}$. Se, em Ser e tempo, o homem poderia ser determinado como uma liberdade finita, dir-se-ia que ele se torna, nas análises subsequentes à publicação de Ser e tempo, nomeadamente em Kant e o problema da metafisica, uma finitude livre. E se a consideração do homem como uma liberdade finita, enquanto ser-no-mundo, impunha a sua determinação como uma liberdade sempre contrariada por um tempo que era indiferenciadamente tentação, a consideração deste mesmo ente como uma finitude livre remetia para a sua situação num tempo que, desenrolando-se a partir de si mesmo, longe de ser um curso opaco e indiferenciado, era constituído pelo acontecimento da história desse mesmo desenrolar-se. O tempo é agora um movimento circular, um giro, que, na sua circularidade, marca o próprio pensar temporalmente determinado como um pensar giratório, como um kehriges Denken. É o giro (a Kehre) pertencente ao tempo assim concebido que exige o giro intrínseco ao pensar da essência do homem, o giro presente na passagem entre a liberdade finita e a finitude livre como determinações desta mesma essência. E é este mesmo giro constitutivo do tempo que permite a diferenciação de eras no seu seio, ou seja, que permite a passagem da indiferenciação do tempo para a concepção do tempo como história, ou seja, como um percurso articulado por fases e etapas entre si diferenciadas, cujo conjunto oferece o aspecto de uma articulação harmónia, de uma concertação, traduzível musicalmente sob a figura de uma fuga.

A partir de 1930, Heidegger começa a rever todas as determinações do ente humano mencionadas em Ser e tempo a partir da radicalização da finitude, assim como da compreensão do tempo como "história do ser" que essa mesma radicalização arrasta consigo. Deste modo, se, em Ser e tempo, o ente humano aparecia como o detentor de uma liberdade essencial, liberdade essa que se determinava como uma liberdade finita, a partir de 1930, pelo contrário, como consequência da radicalização da finitude humana, este mesmo ente surgia como possuído por uma liberdade que, consequentemente, já não podia ser uma liberdade humana. Daí que Heidegger possa escrever, em Da essência da verdade, na primeira formulação desta liberdade não humana, que "o homem não "possui" a liberdade

${ }^{66}$ Cf. Jean GRONDIN, Le tournant dans la pensée de Martin Heidegger, Paris, PUF, 1987, p. 81.

67 Martin HEDEGGER, Kant und das Problem der Metaphysik, Frankfurt am Main, Vittorio Klostermann, 1998, p. 228.

68 Idem, p. 229. 
como propriedade» e que «a liberdade $[. .$.$] possui o homem» { }^{69}$, o qual existe apenas como «propriedade desta liberdade» ${ }^{70}$.

Heidegger apressa-se aliás a expor publicamente as consequências da radicalização da finitude. Em lições justamente intituladas Da essência da liberdade humana. Introdução à filosofia, lidas logo no Semestre de Verão de 1930, é possível ler claramente que a liberdade «é, na sua essência, mais originária que o homem», que o homem «é apenas um administrador da liberdade» e que «a liberdade humana já não quer dizer agora liberdade enquanto propriedade do homem, mas, ao contrário, o homem como uma possibilidade da liberdade» ${ }^{71}$. A disposição, a compreensão e a fala, apontados em Ser e tempo como as estruturas fundamentais que determinam a existência humana (os chamados existenciais), são aqui já não propriedades do ente humano, mas justamente estruturas nas quais o próprio tempo determina a disposição, a compreensão e a fala do homem. Este tempo, na diferenciação que lhe é intrínseca, articula-se em si mesmo como uma harmonia, como uma fuga musical onde a sua diferenciação por diversos percursos encontra uma concertação definitiva. É já nas lições do Semestre de Verão de 1934 que, pela primeira vez, Heidegger pode caracterizar o tempo não apenas como um poder ao qual o homem se encontra submetido, mas também como uma "fuga" constituída por uma diferenciação intrínseca de percursos: «O tempo, experimentado como a nossa determinação, nada mais é do que a articulação de poder [Machtgefüge], a grande e singular fuga [Fuge] do nosso ser enquanto ser histórico» ${ }^{72}$. É em referência a este poder do tempo que Heidegger poderá escrever, nas lições seguintes, que «a linguagem não é nada que o homem tenha, mas, pelo contrário, aquilo que tem o homem» ${ }^{73}$. Não é o homem que se dispõe ou se indispõe, que compreende, que fala. Pelo contrário, ele é agora apenas disposto, compreendido e falado pelo tempo que se desenrola como um acontecimento que dele se apropria. É num tal acontecimento-apropriante (Er-eignis) constitutivo do tempo que consiste aliás o conceito mais fundamental da própria história do ser. No seguimento do processo de radicalização da finitude, dir-se-ia que o homem não tem já uma história ou uma "vida" que se oferece como o tempo indiferenciado onde a sua liberdade se exercita, sob a forma de uma decisão sempre contrariada e repetida. Pelo contrário, enraizado na sua finitude, é agora a história que tem o homem, desenrolando-se como um acontecimento que se apropria desse mesmo homem como o ente através do qual ela pode vir a ser.

É nos Contributos para a filosofia (do acontecimento-apropriante), escritos entre 1936 e 1938, que Heidegger reelabora a analítica de Ser e tempo à luz da radicalização da finitude e, consequentemente, do aparecimento de um tempo entendido como história do ser. O homem, enquanto aí-ser, já não é aqui, como em Ser e tempo, um ente que se refere ao ser. Pelo contrário: ele é o próprio ser que, desdobrando-se na sua história, acontece apropriando o "aí" do ente humano. Através da radicalização da finitude, através do enraizamento do homem numa história que nele e através dele acontece, «o acontecimento-de-apropriação [Er-eignung] determina o homem como propriedade do Ser» ${ }^{74}$ A essência do homem não é então humana. Ela é, entendida num sentido verbal (entendendo-se Wesen como um

GA31, pp. 134-135.

2 GA38, p. 130.

73 GA39, p. 174.

74 GA65, p. 263. 
infinitivo verbal substantivado), uma história que "é" enquanto "vigora" (este Wesen consiste num Walten) como essência de um "aí". Por outras palavras, o homem é, na sua essência, o próprio ser que, constituído como uma história e, enquanto história, como um acontecimento-apropriante, vem a ser na e através da determinação e apropriação do homem.

\section{A história do ser e a possibilidade da ética}

Tendo em conta que a partir de Ser e tempo ocorre uma radicalização da finitude do homem, de tal modo que, entre 1927 e 1929, o homem "gira", passando de liberdade finita a finitude livre, e que esta radicalização da finitude tem como consequência a determinação do ser como história e do homem, enquanto aí-ser, como acontecimento apropriado por esta mesma história, torna-se então necessário perguntar de que modo esta radicalização da finitude, assim como o pensar da história do ser que tal radicalização introduz, poderia possibilitar o aparecimento de uma ética. Partindo do princípio de que a radicalização da finitude e o pensar da história do ser estão articulados com o desenvolvimento do projecto da ontologia fundamental, ou seja, com o "giro" da ontologia fundamental para as metaontologias nela fundadas, particularmente para a elaboração da "questão da ética", tal como Heidegger o expõe em 1928, torna-se necessário perguntar em que sentido é que esta articulação se pode estabelecer. Como é que o homem finitizado da história do ser tem acesso a uma existência autêntica, compreendida como alternativa fáctica à inautenticidade? Eis a formulação mais simplificada que a questão poderia assumir.

Para responder a esta pergunta, é imprescindível reparar na consequência fundamental da emergência do pensar da história do ser. Tal pensar pensa o ser como um acontecimento que se desenrola não propriamente no tempo, mas enquanto o próprio tempo. Tal quer dizer que o tempo é o desenrolar-se da história do ser, sendo, nessa medida, constituído pelas diferentes fases deste mesmo desenrolar-se. Por outras palavras, o tempo já não é visto, como em Ser e tempo, como um percurso indiferenciado, como a sede onde decorre uma vida que é indiferenciadamente tentação, segundo a equação augustiniana da "vita = tentatio tota", mas como o desenrolar-se de uma história que se diferencia em eras distintas.

O pensar da história do ser permite assim a Heidegger a elaboração de uma "crítica do tempo", para usar a expressão de Walter Rathenau, ou seja, a tematização daquilo a que, no contexto de uma história do ser, se poderia chamar o "tempo hodierno". E importa notar que o "tempo hodierno" não consistia num tema novo para a filosofia de Heidegger. Pelo contrário, um tal tema tinha sido já tratado no contexto das lições do primeiro período de Freiburg, sendo progressivamente abandonado quando o projecto de Ser e tempo começa a ganhar consistência.

O tema do "tempo hodierno", particularmente na Alemanha dos anos 20, relacionava-se, mais uma vez, com o contexto de uma crítica católica à ética protestante esboçada por Weber. Weber associa directamente protestantismo e modernidade. Para a "ética protestante", se os homens estavam já ab initio ou salvos ou votados à perdição, nenhuma obra poderia ter a eficácia de mudar esse decreto eterno. Deste modo, nenhuma intervenção "mágica", nenhum milagre poderia operar num mundo que, como tal, está totalmente "desencantado", despojado de qualquer sacralidade e aberto à sua exploração e violação por um sujeito moderno cujo poder já não reconhece limites ou vínculos. E se o protestantismo surge, na análise weberiana, como a espiritualidade própria da modernidade, a espiritualidade católica surge diante desta como essencialmente antimoderna. Na sua confrontação implícita 
com o protestantismo caracterizado por Weber, Heidegger, na sequência aliás da influência de teólogos como Carl Braig ${ }^{75}$, assume claramente esta antimodernidade decorrente do catolicismo.

É nas lições do Semestre de Verão de 1923, intituladas Ontologia (hermenêutica da facticidade), que aparece o tema do "tempo hodierno"76. E um tal tempo surge justamente marcado sob o signo da modernidade. Ele é caracterizado como o tempo de uma "“intelectualidade" moderna»" ${ }^{77}$, denunciada pelo tagarelar (Gerede) próprio da mediania onde «até se escrevem livros a partir do ouvir-dizer» ${ }^{78}$. Ou como o tempo da «máscara» de uma funcionalidade cuja "vitalidade suprema (nomeadamente da empresa) $\gg^{79}$ furta o homem a um encontro consigo mesmo. Ou como o tempo de uma vida pública assente na curiosidade, «em que cada um facilmente fica a par do que se passa, em que nada do que se passa lhe escapa» ${ }^{80}$. Numa palavra, ele é caracterizado pelas notas próprias de uma era específica. É certo que Heidegger, nestas lições, atribui aos termos hoje e hodierno uma certa ambiguidade. Estes são apresentados não apenas como significando uma era ou um tempo específico, mas o carácter situado do homem enquanto tal, ou seja, o seu vínculo a uma situação fáctica e a um tempo determinados. Daí que «o "hoje"» seja, "segundo o seu carácter ontológico», o «como da facticidade (existência)»" Contudo, os próprios termos fazem com que, no decorrer das lições, a análise de Heidegger se refira não ao "hoje" enquanto "como da facticidade", enquanto determinação da existência enquanto tal, mas enquanto modo de vida de uma era específica. O "hoje" é, nestas lições, o "nosso tempo" enquanto determinação da facticidade. E é para a caracterização deste "nosso tempo", determinado pela era moderna, que surge aqui o conceito de quotidianeidade. A quotidianeidade tem então, nestas lições, o significado da expressão «"hoje", nos nossos dias» ${ }^{83}$.

Nas lições que se seguiram a Ontologia (hermenêutica da facticidade) é possível observar, na elaboração do conceito de quotidianeidade, a influência crescente da concepção augustiniana de um tempo indiferenciado, assim como da vida como tentação. Tal influência faz com que o conceito de quotidianeidade perca a sua referência ao hoje, à modernidade do "tempo hodierno", passando a confundir-se com a inautenticidade enquanto marca constitutiva da facticidade. A partir das lições de 1923, Heidegger fala já não de um tempo constituído pelas marcas da quotidianeidade, mas destas mesmas marcas enquanto determinações do tempo ou, o que é o mesmo, da facticidade da existência enquanto tal. Dir-se-ia que se, nas lições de 1923, Heidegger fala ainda de um tempo da quotidianeidade, ele começa a falar, a partir destas mesmas lições, de uma quotidianeidade do tempo. Deste modo, nas lições que preparam Ser e tempo, assim como na própria obra de 1927 , o conceito de quotidianeidade fica ferido por uma ambiguidade fundamental.

75 Sobre a influência de Carl Braig em Heidegger, cf. Richard SCHAEFFLER, "Heidegger und die Theologie" in Heidegger und die praktische Philosophie (ed. Annemarie GethmannSiefert e Otto Pögeller), Frankfurt am Main, Suhrkamp, 1989, pp. 293 ss.

76 GA63, p. 29 ss.

77 GA63, p. 33.

78 GA63, p. 32.

79 GA63, p. 32.

80 GA63, p. 31 .

81 GA63, p. 31.

82 Cf. GA63, p. 30.

83 GA63, p. 30. 
Por um lado, sobretudo a partir de 1923, a quotidianeidade não é ligada a qualquer tempo específico, deixando-se pressuposto que o ente humano, na medida em que existe facticamente como ser-no-mundo, e na medida em que tal se traduz num modus inautêntico de ser, existe sempre à partida na inautenticidade de um quotidiano. Mas, por outro lado, ela não pode deixar de ser portadora das marcas da sua origem, ou seja, das marcas de uma "crítica do tempo", no sentido de uma "crítica da modernidade", continuando a ser assinalada através de características e exemplos que são próprios não do ser-no-mundo enquanto tal, mas justamente de um "tempo hodierno".

A análise da existência quotidiana permite a Heidegger assinalar o homem desta existência através da impessoalidade de um "se". As novidades constantes que dispersam o homem numa curiosidade saltitante e inconsequente, a mediania da vida pública, a redução à funcionalidade, o tagarelar sobre a moda, os lugares comuns e as banalidades partilhadas por toda a gente - tudo isso constitui um modus quotidiano de existir pelo qual cada um se confunde com cada um. Heidegger refere-se sempre a este "se" da quotidianeidade como se este determinasse não um tempo, mas o próprio tempo em que a vida humana decorre. Ele é, como escreve em 1923, «o "ninguém" que, como um fantasma, rodopia no aí-ser fáctico, um como da fatalidade específica da facticidade, a quem cada vida fáctica paga o seu tributo» ${ }^{84}$. Neste sentido, o "se" determina já toda a actividade do homem enquanto tal. Ele é, como Heidegger escreve já em 1925, pura e simplesmente «o que se faz. [...] O se é sapateiro, alfaiate, professor, banqueiro» ${ }^{85}$. Deste modo, pelo menos desde as lições do Semestre de Verão desse ano, intituladas Prolegómenos para a história do conceito de tempo, Heidegger faz o esforço de identificar a quotidianeidade com a própria inautenticidade. E é esta identificação que caracteriza o tratamento do conceito de quotidianeidade em Ser e tempo.

Contudo, a leitura de Ser e tempo permite verificar facilmente que, embora Heidegger não se refira ao "se" da quotidianeidade como um fenómeno próprio de um tempo específico, é justamente o "hoje" dos tempos modernos que, com o conceito de quotidianeidade, é por ele efectivamente visado. O "se" da quotidianeidade, embora o peso do cunho augustiniano de Ser e tempo não permita a Heidegger afirmá-lo abertamente, não caracteriza uma quotidianeidade constitutiva da existência humana enquanto fáctica, uma quotidianeidade que se confunda com um modus essencial da vida do homem, mas, pelo contrário, apenas uma quotidianeidade hodierna. Os exemplos escolhidos por Heidegger para o ilustrar são suficientemente esclarecedores: «Na utilização dos meios de transporte públicos, no uso dos meios de informação (jornais), cada um é como o outro. [...] Fruímos e divertimo-nos como se frui; lemos, vemos e julgamos sobre literatura e arte como se vê e julga; mas também nos retiramos da "grande multidão" como se se retira; achamos "escandaloso" aquilo que se acha escandaloso» ${ }^{86}$. Deste modo, se em Ser e tempo, devido à preponderância da equação augustiniana "vita = tentatio tota", Heidegger nunca se referirá ao carácter hodierno da quotidianeidade, este mesmo carácter não poderá deixar de regressar, no momento em que a preponderância desta mesma equação se atenua.

Com a radicalização da finitude da existência, assim como com a emergência da história do ser que a esta radicalização sucede, as características que Ser e tempo 
atribuía à quotidianeidade (isto é, à inautenticidade e à decadência) dirigem-se então abertamente a uma história possível da existência enquanto aí-ser, não $a ̀$ história constitutiva dessa mesma existência enquanto tal. Heidegger pode agora indicar um tempo de autenticidade e de grandeza, um tempo que se liberte da decadência própria de $u m$ tempo quotidiano. Mas onde situar este tempo não quotidiano? Onde situar o tempo onde a autenticidade, na liberdade que a constitui, pode surgir como efectiva e concreta? Se a autenticidade é caracterizada, enquanto liberdade, como uma possibilidade de inauguração e de abertura, como uma Eröffnung, o tempo da autenticidade não poderá deixar de ser um tempo inicial. É neste sentido que as referências de Heidegger a um início - o início grego da história ocidental assinalam justamente o carácter de um tempo marcado pela autenticidade de uma existência ideal facticamente possível. Deste modo, é possível dizer que este início da história tem uma dupla missão. Por um lado, ele mostra que a autenticidade na história é possível, isto é, que o tempo não é indiferenciadamente um tempo de inautenticidade e decadência. Por outro lado, ele manifesta que, mesmo num tempo de decadência, há sempre a referência indestrutível de uma autenticidade, de um ideal fáctico possível, de um início arquetípico que, ao contrário de um mero começo, não se esvai com o passar do tempo ${ }^{87}$. Dai que Heidegger possa escrever, justamente no discurso do reitorado, onde a autenticidade teria de emergir como um êthos, como um modo de vida alternativo à inautenticidade: «O início ainda é. Ele não repousa apenas atrás de nós como algo que foi há muito, mas ele está diante de nós. O início passou já à partida, enquanto maior, sobre tudo o que vier e assim também sobre nós. O início entrou no nosso futuro, ele está lá sobre nós como a ordem distante de alcançar novamente a sua grandeza» ${ }^{88}$. Por outras palavras, a referência a um início da história marcado pela autenticidade e pela grandeza, anulando a concepção de uma vida e de um tempo determinados pela tentação e pela decadência da inautenticidade, possibilitava a Heidegger a alusão a uma ética distinta. Ao homem era possível agora, escapando a uma inautenticidade decadente e tentadora, recuperar a grandeza do início, trabalhando, fazendo obra, agindo na direcção da passagem para um outro início da sua própria história.

Diante da concepção de um primeiro início da história, e da exigência da passagem para o seu outro início, emerge novamente, por uma última vez, a pergunta fundamental da ética, a pergunta acerca de se e como a liberdade é possível. E a sua nova formulação não pode deixar de perguntar pela possibilidade da liberdade sob a referência de um homem determinado como finito, como enraizado numa história que se constitui como um acontecimento-de-apropriação, como uma Er-eignung. Se o homem não é senão o "aí" do ser, se ele está, enquanto finito, essencialmente entregue ao poder de um tempo que dele se apropria, como pode ele, a partir de si mesmo, iniciar? Será que o homem, entregue à supremacia do tempo, entregue à Übermacht da história, determinado e apropriado pelo tempo constitutivo da história do ser, é livre? Heidegger não pode deixar de responder, pelo menos implicitamente, a esta dificuldade. E responde esclarecendo o próprio significado do início no contexto da história do ser. A liberdade humana é sempre possível como resposta ao apelo para a re-tomada (no sentido da Wieder-holung) do início. Mas, num tempo determinado como história do ser, é sempre esta mesma história, e nunca o homem, que pode propriamente iniciar. Deste modo, retomar o 
início consiste não em saltar para fora de uma história de decadência, não em passar para um outro início da história, mas em apenas preparar a passagem. É então na preparação de uma passagem cujas consequências lhe escapam, numa acção que pode permanecer invisível, que o homem encontra finalmente a sua liberdade. O seu agir pode ser silenciado por um tempo que o torna imperceptível. Este silenciamento, este anonimato no seio da agitação tumultuosa do tempo, é até provável. Heidegger esclarece aliás que «o fim do primeiro início alastrará ainda longo tempo para a passagem, e mesmo para o outro início» ${ }^{89}$. E a liberdade estará então, definitivamente, não na possibilidade de efectivar a passagem para o outro início, mas na possibilidade de sempre tentar a sua efectivação, através de um pensar e de um poetar originários, ạtravés de um Erdenken e de um Erdichten, mas também através de um agir sempre preparatório mas sempre essencial. 